3. Baxmann AC, Ahmed MS, Marques NC, Menon VB, Pereira B, Kirsztajn GB, et al. Influence of muscle mass and physical activity on serum and urinary creatinine and serum cystatin C. Clin J Am Soc Nephrol. 2008;3(2):348-54.

4. Gutierrez A, Alvestrand A, Qureshi GA, Bergström J. Influence of a meat-free diet on the urinary excretion of 3-methylhistidine and creatinine in chronic renal failure. J Intern Med. 1992;232(2):129-32.

5. MacIsaac RJ, Ekinci EI, Premaratne E, Lu ZX, Seah J, Li Y, et al. The Chronic Kidney Disease-Epidemiology Collaboration (CKD-EPI) equation does not improve the underestimation of glomerular filtration rate (GFR) in people with diabetes and preserved renal function. BMC Nephrol. 2015;16:198.

6. Wołyniec W, Ratkowski W, Kasprowicz K, Jastrzębski Z, Małgorzewicz S, Witek K, et al. Glomerular filtration rate is unchanged by ultramarathon. J Strength Cond Res. 2018;32(11):3207-15.

7. Odutayo A, Cherney D. Cystatin C and acute changes in glomerular filtration rate. Clin Nephrol. 2012;78(1):64-75.

8. Machado JCQ, Volpe CMO, Vasconcellos LS, NogueiraMachado JA. Quantification of NGAL in urine of endurance cycling athletes. J Phys Act Health. 2018;15(9):679-82.

9. Wołyniec W, Ratkowski W, Urbański R, Bartoszewicz M, Siluk D, Wołyniec Z, et al. Urinary kidney injury molecule1 but not urinary neutrophil gelatinase associated lipocalin is increased after short maximal exercise. Nephron. 2018;138(1):29-34.

10. Sánchez-Lozada LG, García-Arroyo FE, Gonzaga G, Silverio O, Blas-Marron MG, Muñoz-Jimenez I, et al. Kidney injury from recurrent heat stress and rhabdomyolysis: protective role of allopurinol and sodium bicarbonate. Am J Nephrol. 2018;48(5):339-48.

\section{Leaf-Cutter Ants in Wound Closure}

To the Editor:

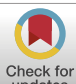

Adequate laceration management continues to challenge providers in resource-poor settings. Even minor lacerations in wilderness scenarios can rapidly lead to significant morbidity. Most noncontaminated lacerations, once appropriately irrigated, can be treated safely with acute primary closure. ${ }^{1,2}$ Multiple commercial options for wound closure are available, including tissue adhesives, surgical tapes, staples, and sutures. However, if wilderness providers do not have ready access to such supplies, they may need to depend on improvised techniques using resources found in the environment.

There may be value in a "natural" method of laceration closure that has not been previously mentioned in recent wilderness medicine literature. Leaf-cutting ants, members of 2 genera-Atta and Acromyrmex (subfamily: Myrmicinae; tribe: Attini) - have been used to close wounds in Central and South America for centuries. ${ }^{3}$ These ants are found in the tropics and subtropics approximately between latitudes $33^{\circ} \mathrm{N}$ and $44^{\circ} \mathrm{S}$, including regions of Texas and Louisiana. ${ }^{4}$ Leaf-cutting ants are usually red-brown in color with 11-segmented antennae, 3 pairs of thorax spines, and a 2 -segmented petiole (narrow waist). Nests are made from soils and can extend up to $1200 \mathrm{~m}^{2}$ in surface area and more than $7 \mathrm{~m}$ deep. These colonies are typically easily identified by their numerous surface-level, crescent-shaped mounds. ${ }^{5}$ Leaf-cutter ants, like many insects, are polymorphic, meaning that within each species there are a variety of body types, with each suited to a specific task necessary for colony survival. The soldier caste of a leafcutting colony is the largest of all castes and defends the colony against threats. Members of this caste are most suitable for the application of wound closure given their larger mandible size.

When primary closure is necessary, both sides of the leaf-cutting ant's head are held firmly between the first and second digits (Figure 1). Gentle pressure is applied, forcing the ant's oral cavity to open. The ant's head is placed perpendicularly to and transversely across the wound. On contact with a surface, such as the skin, the oral cavity quickly closes, bringing the 2 sides of the wound together in apposition. The thorax and abdomen of the ant are subsequently detached, leaving the head and mandible behind. The decapitated head reportedly stays in place for approximately $3 \mathrm{~d}^{3}$; however, there is no literature detailing such information or the rates of dehiscence.

Some anecdotal reports indicate that wounds closed with leaf-cutter mandibles are less prone to infection than untreated lacerations. This may be secondary to the leaf-cutter ant's natural chemical defenses against parasites. The metapleural glands of this type of ant secrete bioactive components that inhibit a range of microorganisms. ${ }^{6,7}$ When the metapleural glands of Acromyrmex octospinosus were artificially occluded, the ants experienced a subsequent increase in susceptibility to invading bacteria. ${ }^{8}$ Unfortunately, there are no studies available to determine whether the metapleural secretions of leaf-cutter ants are active against human skin pathogens.

Leaf-cutter colonies can contain millions of individuals, allowing ants to be a readily available and renewable resource. Although there is not enough evidence to recommend this means of wound closure over commercially available devices, in appropriate situations with limited supplies, this may be a worthwhile option. Additional investigation into this means of laceration repair is certainly warranted.

Acknowledgments: The author thanks Taylor Marks, BS, with assistance with photography used in Figure 1. 

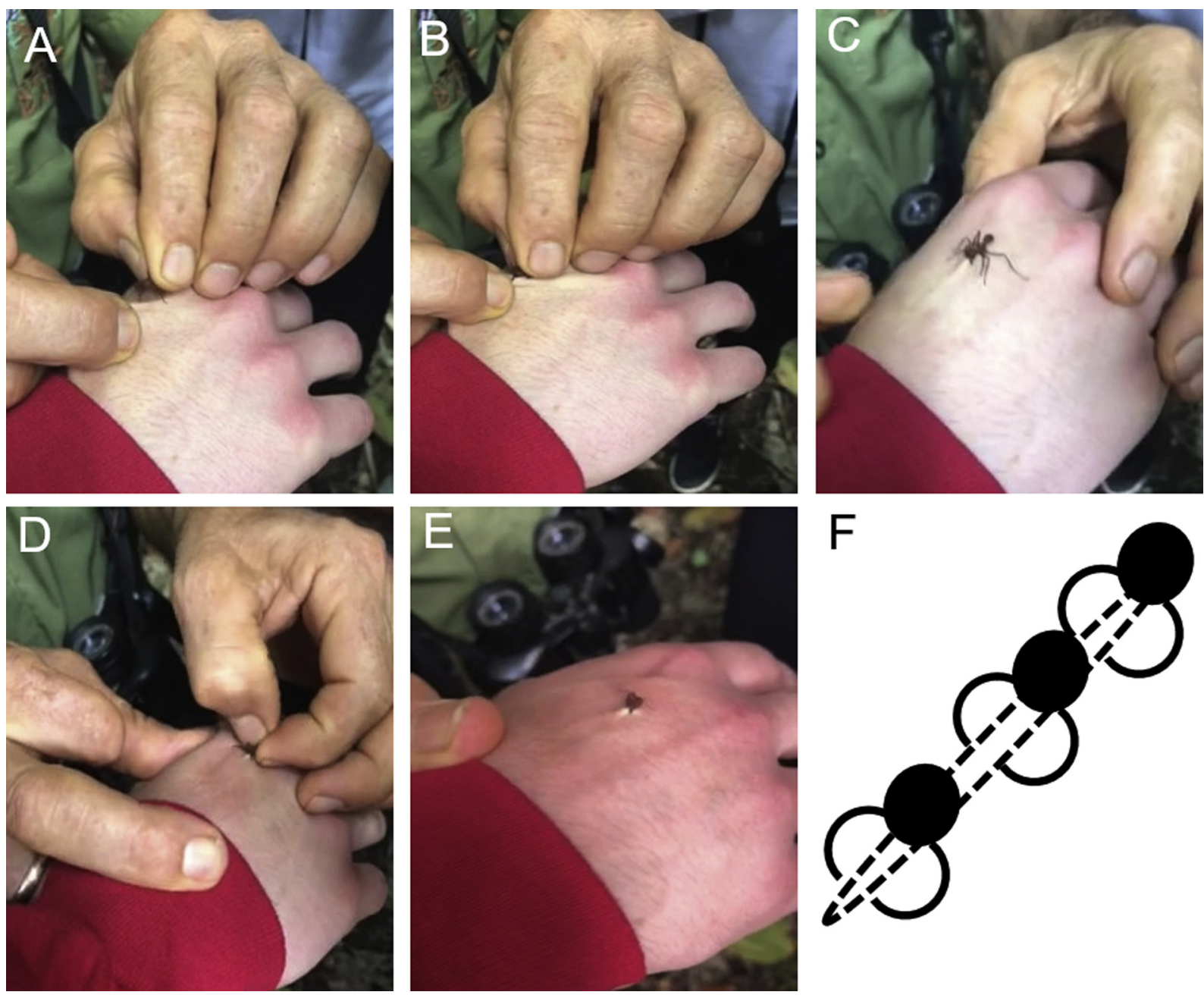

Figure 1. Attachment of a leaf-cutter ant: (A) positioning of ant; (B) closure of ant's mandible; (C) ant secured on skin; (D) decapitation of ant; (E) completed ant suture; and (F) pictorial of multiple ant sutures to close a wound.

Hillary E. Davis, MD, PhD Emergency Medicine University of Colorado, Denver Denver, $C O$

\section{References}

1. Davis KP, Derlet RW. Cyanoacrylate glues for wilderness and remote travel medical care. Wilderness Environ Med. 2013;24(1):67-74.

2. Quinn RH, Wedmore I, Johnson EL, Islas AA, Anglim A, Zafren K, et al. Wilderness Medical Society practice guidelines for basic wound management in the austere environment: 2014 update. Wilderness Environ Med. 2014;25(4): S118-33.

3. Gudger EW. Stitching wounds with the mandibles of ants and beetles. A minor contribution to the history of surgery. JAMA. 1925;84(24):1861-4.
4. Schowalter TD, Ring DR. Biology and management of the Texas leafcutting ant (hymenoptera: formicidae). J Integr Pest Manag. 2017;8(1):1-8.

5. Alejandro-Gustavo-Farji B, Ruggiero A. Leaf-cutting ants (Atta and Acromyrmex) inhabiting Argentina: patterns in species richness and geographical range sizes. $J$ Biogeogr. 1994;21(4):391-9.

6. de Lima Mendonça A, da Silva CE, de Mesquita FLT, da Silva Campos R, Do Nascimento RR, de Azevedo Ximenes ECP, et al. Antimicrobial activities of components of the glandular secretions of leaf cutting ants of the genus Atta. Antonie van Leeuwenhoek. 2009;95(4):295-303.

7. Samuels RI, Mattoso TC, Moreira DDO. Chemical warfare. Commun Integr Biol. 2013;6(2):e23095.

8. Poulsen M, Bot ANM, Boomsma JJ. The effect of metapleural gland secretion on the growth of a mutualistic bacterium on the cuticle of leaf-cutting ants. Naturwissenschaften. 2003;90(9): 406-9. 